Nepalese Culture

Vol. XIV : 13-25, 2021

Central Department of NeHCA,

Tribhuvan University, Kathmandu, Nepal

DOI: https://doi.org/10.3126/nc.v14i0.35422

\title{
Learning Lessons, Challenges, Impacts \& Solutions on the Path of Recovery from Covid-19 in Nepal
}

\author{
Poonam R L Rana, Ph.D \\ Associate Professor \\ Central Department of Nepalese History, Culture and Archaeology, T.U. \\ E-mail : poonamrlrana3@gmail.com
}

\begin{abstract}
The research study focuses on the impact of Covid-19 on Tourism in Nepal and looks into the challenges to face in the path of recovery and to bring to light the lessons learned from COVID 19. It is qualitative in nature including both primary and secondary sources. 50 respondents were chosen as samples. The results showed that, there was drastic impact on tourism sector affecting national economy, It has brought to light various challenges to be faced in path of recovery and the greatest lesson learnt is that the government should develop its health sector and the people should always be strong and prepared to face any disaster or pandemics at all times. Solutions are provided in form of recommendations.
\end{abstract}

Keywords: Covid-19, tourism, impact, challenges, lesson learnt.

Dr. Poonam R L Rana is Associate Professor, in the Central Dept. of Nepalese History Culture \& Archaeology, is the author of Nepalese Ethnic Costumes \& Ornaments \& Toni Hagen's Photos of Kathmandu Valley (1950s -60s), She has been Visiting Scholar to Sichuan University, Yunnan Minzo University \& Tibetan University and has been invited by National University of Singapore. Email: poonamrlrana3@gmail.com

\section{Introduction}

Nepal is an enchanting land that lies along the foothills of the great Himalayas. It is a small country yet has extreme topographical variations leading to a conglomeration of unique diverse ethnic groups and their cultural variety, thereby enticing the outside world. It has rare wildlife, and is renowned for trekking destinations with trekking routes like Annapurna and Everest treks. Due to these attractions, Nepal has become tourist destination. Historically before 1950s, Nepal observed close door policy, after 50s it opened its door to 
the outside world and with it, this virgin land became interest of the world. Now Tourism is one of the largest industries in Nepal. Last year 2019, Nepal's tourism industry generated Rs. 240 billion and supported more than 1 million jobs. (Source: NTB ). The coming of Coronavirus has badly hit the Nepal's tourism-based economy. The country seemed hopeful when Nepal's Tourism Minister Yogesh Bhattarai claimed that Nepal was a "Coronavirus free Zone and he invited foreigners to travel to Nepal without any fear". (Source Ministry of Tourism). But recently due to rise in the numbers, this slogan seems a far-off thought. The research study focuses on the impact of Covid 19 on Tourism, looks into the challenges to face in the path of recovery and to bring to light the lessons learned from COVID 19.

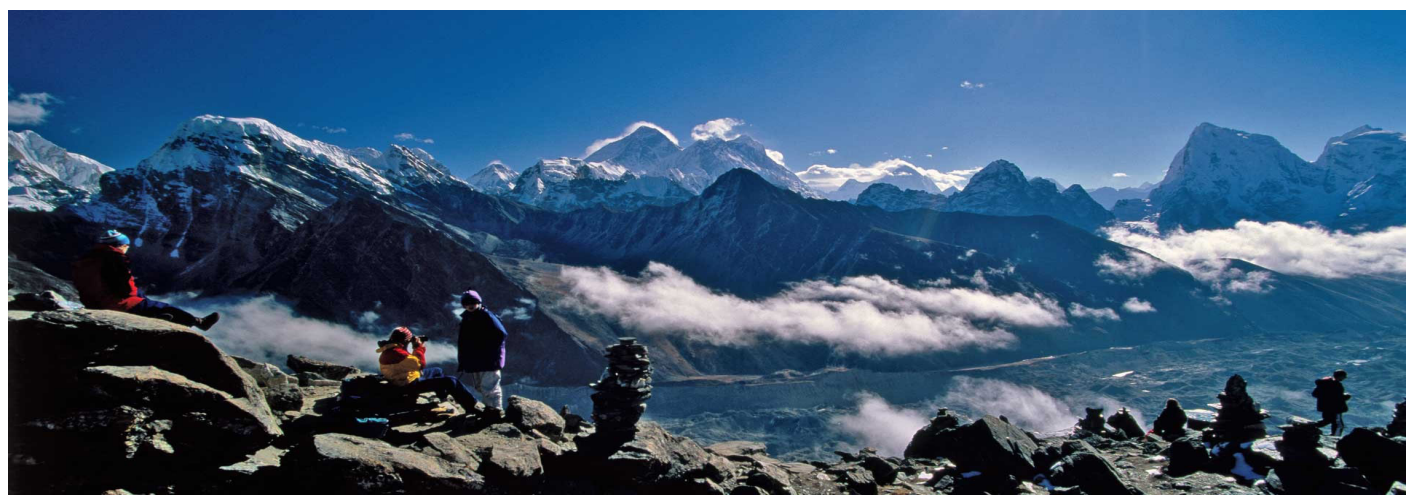

Figure 1: View of Everest Region

Source: Travel \& Tourist Information

\section{Background}

Covid 19 is corona-viruses, first found in 1960s, affect the upper respiratory tract in children and the elderly. In 2003, at least 5 different types of corona-viruses were identified, including the severe respiratory syndrome corona-virus, that caused significant morbidity and mortality. The identification of group II corona-virus, HKU1, has yet to be established. Corona-virus has grown in the past few years. It was the SARS epidemic that put the animal corona-viruses in the spotlight. (Tyrrell DA, Bynoe ML.etl. 1966; 76-77.) In January, 2020, the outbreak of the 2019 corona-virus (2019-nCoV) in China spread progressively to other countries, and WHO declaring it a Public Health Emergency of International Concern. (Huang C Wang Y Li X et al, 2020 ) Among the affected countries beside China (where 12307 cases and 259 deaths were reported as of Feb 1, 2020) are others in Asia, including Nepal. 


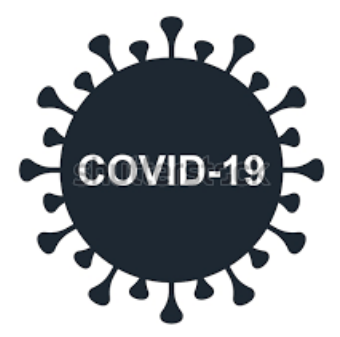

\section{Figure 2: COVID -19}

The first case on Jan 13,2020, was a 32-year-old man, who was Nepalese student at Wuhan University of Technology. He returned to Nepal. As he was suffering from cough he became an outpatient in Sukraraj Tropical and Infectious Disease Hospital at Kathmandu. The throat swabs obtained from the patient tested positive with it began COVID-19 in Nepal.

As to who is to be blamed for Covid-19, Prof Aubrey Manning (Zoologist) mentions " Human has existed for 200,000 years, our impact on earth is so great that scientist have termed it as "ANTHROPOCENE" The Age Of Human. The changes made by us have extracted a heavy toll on the Natural World. Species are becoming 100 times extinct faster, due to human impact and biodiversity is lost. Large scale of industrialization has lead to high percentage of Co 2 emission that is turning seas, rivers into dead zone; global warming causes glacial melting leading to rise in the sea level, severe weather, flood, draught and hurricane. Fifth mass extinction lead to wipe out of Dinosaurs and the scientists have named today's phase as the "' Sixth Mass Extinction' (BBC: Rules of Life - Meet Aubery, 24 October 2005)

It is best we realize and understand its impact before it's too late. COVID-19 is also a part of natures check and balance on the species, we maybe intelligent, may even act as God by creating living zombies; where heart is replaced by machines, blood replaced by plasma etc. There is no end to it. We have become creators and challenged the one who created the species 'Mankind'. We are our own enemy, paving way to our own extinction.

Jason Moore relates Capitalocene to Anthropocene and adds that it is a kind of critical provocation to this sensibility of Anthropocene; which is: We have met our enemies who is it? It is us, now; we must cover our footprints. How? Be more sustainable consumer, and pay more attention to nature and population growth. (. Maize, 2019, 6, 49-54)

In the context of Nepal and its tourism sector the Asian Development Bank (ADB) Report (2019), is of the view that tourism industry has a distinctive place in Nepal's economy and the industry. Before the outbreak of the pandemic, it generated $12125 \%$ of the total foreign exchange and provided direct employment to more than 200,000 people. The research shows 
that the average direct contribution of tourism to the national economy was about $3.9 \%$ in the GDP in 2008-2018 (ADB, 2019). Nepal's economy has started to suffer from the initial phase of outbreak of the virus. Nepal's tourism-based economy is severely hit. due to travel restrictions imposed by Nepal and other countries, with the airlines cancelation of flights. (Subba, 2020). Research conducted brings to light that China is the second highest source of tourist in Nepal; who contributed $20 \%$ to the hotel occupancy. With the restrictions on travelling by Government of China has dwindled the economic resources. According to the Central Bureau of Statistics this sector contributes 14.37 percent to the economy. (Shrestha, 2020)

In 2018 the Tourism revenue was $7.9 \%$ of the country's GDP and it supported 1.05 million jobs, and had expectation of providing 1.35 million jobs by the year 2029. In 2019, Nepal became host for 1.19 million foreign tourists. In $1^{\text {st }}$ Jan 2019, and the 'Visit Nepal 2020 ' campaign was officially introduced to attract 2 million tourists and to generate $\$ 2$ billion and to create thousands of new jobs. (World Bank in Nepal 2020,) Tourism industry has been christened as a "fickle" industry, "seasonal" industry, "peace" industry, is one of the "largest" industries (Kunwar, 2010, p.12). Earlier tourism was the greatest source of National income but today remittance has overtaken it. However, the arrival of 'CORONA' in 2020. The national income has come crashing down.

A theory known as 'Tourism Crisis' was a theory developed by Beirman (2011), he defines crisis as, " an event or set of circumstances which can severely compromise or damage the marketability and reputation of a tourism business or an entire tourism development region." As per (Henderson 2007; in Kunwar, 2016, p.16). Crises in tourism can affect the development of economic, political, socio-cultural and environmental sectors that can further affect demand and supply in tourism generating countries. With strategic plan of crisis management, there is possibility of reducing the impacts; therefore, evaluation of such strategic plans can help to some extent to face crises.

On 23 January 2020, the first case of imported COVID-19 was found in Nepal. In response to the worldwide Covid-19 crises, the government suspended the 'Visit Nepal $2020^{\prime}$ ' on $3^{\text {rd }}$ March 2020. After the WHO, declared COVID-19 a pandemic on 13 March 2020. Nepal government suspended all permissions for mountaineering expeditions and the visas.( Shrestha R, Shrestha S, Khanal P, Bhuvan KC. TravelMed 2020. )

\section{Methodology of Study}

The major research problem is that there has been numerous minor studies on COVID-19 and its impact on tourism but, the greatest problem is that there has been $\underline{\mathbf{n o}}$ study on Learning lessons from COVIS-19. 
The major objective or the research questions to investigate is as follows the impact of COVID-19 in the Tourism Sector of Nepal. Also to find out the challenges in the path of recovery and what lessons has COVID-19 taught in promotion of tourism; beside opening new venue for further research.

The Qualitative research is a multi-method that is exploratory in nature and focuses on interpretative, naturalistic approach to its subject matter also termed as Triangulation method. (Denzin \& Lincoln 1994:2). This research is qualitative in nature; where triangulation methodology involving more than one method to acquire the data was utilized. Richards defines triangulation as an interdisciplinary approach which covers multiple methods, multiple sources of data (Richards, 2005:21). The Primary data's were collected through observation, email questionnaires, telephone interviews. (50 respondents questionnaires were collected and analyzed) and secondary sources included E- library study and online Journals review and other books available. The researched books and websites and others sources are cited in the reference section.

The main limitation of this research focus on main 3 objectives in general that is its greatest limitation. The data collected is limited to not more than 50 sample population in the field of tourism, hotel sector, governmental services and students involved in tourism studies sector, hence result obtained may not signify whole of Nepal.

The major significance of this research highlights the situation of COVID-19 its impact on tourism sector of Nepal and it examines to find out challenges to face in path of recovery. This research also brings to light the truthful 'Lesson Learnt' from COVID - 19 and mentions recommendations.

\section{Results / Discussions based on the research questions / Objectives}

\section{Impact of Covid-19 on Tourism Sector of Nepal}

The impact of Covid-19 has transformed tourism sector of Nepal.

The research questions administered brings to light majority of the respondents' claim that due to Covid-19 there has been great economic crises both nationally as well as individually; leading to reduction in foreign currency, financial problem faced by those in this sector and other sectors. Loans and its interest seem to be on rise, creating another problem. It has affected both small local and big well established vendors and local handicrafts. In Nepal, 'No tourists / tourism means no economy'.

The research data brings to light that due to Covid19 there has been increase in unemployment, many have lost their jobs in all sectors; especially in the tourism sector that was once flourishing in Nepal. Now those who were involved in travel tourism, local guides, trekkers, mountaineering, hotel, motel and even home-stays have been forced to change their mind to choose different profession owing to Covid-19. 
Respondents view that Covid-19 has halted flights, airlines, airports all around the world have been shut down. Tourists are unable to travel. O\% tourist means $0 \%$ financial outcome in Nepal. Travel and trekking agencies are on the verge of close down. There has also been a pause in exploration of new destinations. Government and all stakeholders in tourism sector are suffering. Whole tourism sector has collapsed completely.

The collected data further brings to the notice that due to pandemic government issued lockdown that has halted the social mobility of general life of the people. It has also affected the festivities and associated rituals. People are worried and tensed regarding survival.

"The movement of human has been suspended, before Covid-19 travel was a machine of enjoyment, now it is fear. Earlier travel was globalized, now it is localized. Before, travel was making friendship, now it is 'social distancing'. Earlier it was highly welcomed, now it is neglected. Seminar has been transformed into webinar, life is transformed into virtual world instead of real world". Today, human beings norms, values, habits, ideology are in the process of transformation. (Kunwar R. Face book post )

Scholars view that the 'Tourism Crises' falls under two context:

1. Perception at individual level (on demand side)

2. Crises Management, at collective level (Supply side).

This has led to 'Post Traumatic Disorder'(PTSD) people affected by fear, anxiety shock and frustration due to, business loss, unemployment, and human toll due to pandemic. Scholars further add that one cannot avoid the psychological effects of Covid-19 crisis. 'The Fear of the Unknown' (Jared Alster, 2020) This brings to light that psychological recovery has to be considered too.

Covid-19 has played a drastic impact in the Tourism sector of Nepal. Nepal has lost remittances and tourism revenues as a result it has crippled the nation's finances. Funding from donor countries to help Nepal's health system, constituted around $50 \%$ of the health budget, but this too will probably decrease, as donors are too suffer from the pandemic. Though, billions of dollars have already been pledged to help Nepal's COVID-19 response. The plans made by the government to overcome regional health disparities, to accomplish the 'Sustainable Development Goals' and to improve the nation's conditions have all been fruitless due to pandemic.

Nepal had evaded the full impact of COVID-19 till $31^{\text {st }}$ May; there were around 1500 confirmed cases, most of which were asymptomatic, with only eight deaths. Now in Nov $21^{\text {st }} 2020$ the scenario is different. Confirmed cases are $-216,966$, Total tests (PCR) - 1,643,899 New tests- 10, 340, In quarantine - 753, In isolation -m 24, 665, Recovered - 191,002, Deaths $-1,298$. Health Ministry claim that up to today $21^{\text {st }}$ Nov 20201,298 
people have lost lives due to Covid-19 in Nepal. 169 - in Province 1, 174 in Province 2, 643 in Bagmati Province, 82 in Gandaki Province, 179 in Lumbini Province, 15 in Karnali Province and 36 in Sudurpachim Province. (The Himalayan Times, $21^{\text {st }}$ Nov 2020). Nepal lacks resources and manpower for the massive testing and treatment of people that may be required. The country's public health and social support systems are under great strain to cope with the number of Covid-19 patients rising. (Sha,Shigdel,Ozaki etal, 2020)

The tourism based sectors of Nepal has started to show its economic impact. The hotel occupancy rates in Kathmandu, Pokhara and Chitawan have fallen by nearly 95 percent. The top ten countries from where Nepal got its visitors are now under high alert. Flights to its neighboring countries have been cancelled up to Dec $15^{\text {th }} 2020$.

Travel Agencies, Trekking and Tour guide sectors have come to a halt. People from various sectors are suffering from unemployment. Tourism sector provided bread and butter to many, due to pandemic, people are slowly going back to their villages as they find no hope here. Majority have taken up agriculture to sustain themselves. But those in the urban areas suffer the most as they have no land to sustain themselves.

In Kathmandu majority were house owners who rented their rooms and homes to those who came here but, after this pandemic, majority have left the valley due to lack of work and shut down of their businesses. Therefore the situation is that lot of houses are labeled 'On Rent'. Thamel area which was thriving with business, and rent paid by the people was extremely high, has also suffered drastically, now it looks desolate and forlorn, with majority shutters with labels' To Let '.

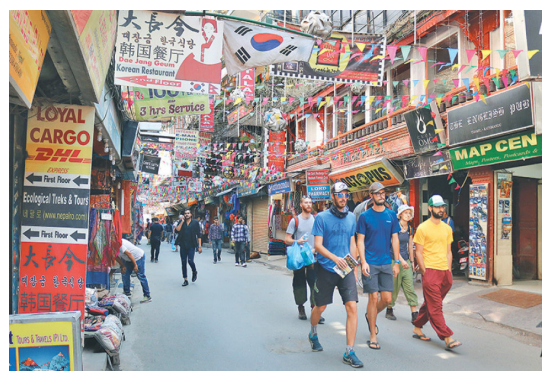

Thamel before Covid-19

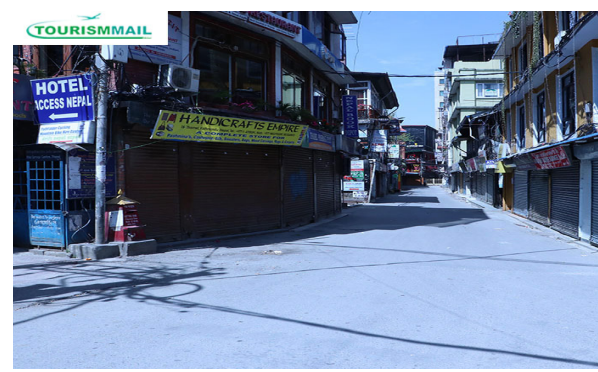

Thamel after Covid-19

The lockdown has badly affected the people who survived on daily wages. Despite the governments promise that 'no one will stay hungry or die from hunger', the issue of people struggling with every day meals is a sensitive matter.

Ableak scenario has been presented by the report of International Labor Organization (ILO), One hundred and sixty million people are going to be unemployed because of the COVID-19 whereas, International Food Organization (IFO) predicts that there could be food 
crisis in upcoming days if it continues to go like this. The International Monetary Fund (IMF) has said that the world's economic growth rate will be only three per cent and that a country like the United States will also have to bear the crises. This pandemic will further expand the economic problems for countries like Nepal.

Nepal is already under economic pressures. The coming of tourist may take longer than witnessed after the 2015 earthquake and remittances may not normalize soon. The government is taking steps to invest significantly in Nepal's agricultural sector and is planning to incentivize migrant workers to stay and work in Nepal, as a means to boost the country's economy in the long-term. The COVID-19 pandemic has made the government and the entire population realize the need for quality in healthcare. The government has increased the health sector budget to over $6 \%$ for the coming fiscal year, although this is still well below the recommendation of WHO (10\%) ( https://academic.oup.com)

With arrival of Covid-19 another impact is on the health sector. There has been lack of testing kits, PPE and medical supplies. Diagnostic and treatment protocols have been established. On $30^{\text {th }}$ May, the government established RT-PCR labs in each province and testing is now available in 20 centers in Nepal and 127 hospitals have been designated as COVID-19 -ready, however there has been lack of hospital rooms and ventilators as well as lack of areas for quarantined people who have arrived from foreign lands. Despite the Government establishment of emergency medical deployment teams at various hub hospitals and medical colleges and is planning to mobilize them as per the need of the provincial and other hospitals too. Yet with increase in the numbers of Covid-19 patients problems keep accumulating. (Sha, Sigdel et.al., 2020 )

The impact of Covid-19 in Tourism sector in Nepal is very high; it has led to crash in the national economy as well as given rise to individual economic crisis.

The challenges faced in the path of recovery are numerous. Such as the recovery of tourism sector of Nepal. The research questions administered to the respondents brings to limelight that majority respondents were of the view that the challenges in path of recovery comprised of various issues such as: lack of professional far-sighted thinkers in government policy making team, low response from governmental side, lack of health security, unemployment, rise in loans and credits, leading businessmen to situation of complete collapse, uncertainty of Covid-19, decrease in businesses both big and small. All these and many other minor challenges were mentioned by them on the path of recovery of tourism in Nepal. Beside what they mentioned the other challenges are as follows

\section{Can 'Travel Bubble' be used in its promotion?}

With the advent of Covid-19 and global close down of borders have lead to the development of this concept 'Travel Bubbles', also known as travel corridors and corona 
corridors. It is a contract or an exclusive partnership between neighboring or nearby countries that have been successful in combating the COVID-19 pandemic within their respective borders. These countries then re-establish connections between them, by opening up borders and allowing people to travel freely within the zone without having the need to undergo quarantine on-arrival.

This term was first pioneered by three Baltic States of Estonia, Latvia and Lithuania, they formed a trilateral partnership that allowed their citizen to enter member territories freely without being quarantined. This free passage was eventually referred to as a 'Travel Bubble'. Slowly this term has been accepted globally. Countries are of the view that the travel bubble concept would help to entail business recoveries across multiple sectors everywhere. ( Further research necessary )

The Government associated Ministry of Tourism must as soon as possible sign 'Travel Bubble' with interested countries and its surrounding neighbours. This may help in path to recovery. However at present it is a great challenge in the path of recovery.

\section{How to promote domestic tourism?}

Another challenge faced is how to promote domestic tourism in the path of recovery. As we know tourism in Asia and the Pacific has been hit hard by Covid-19 pandemic. The arrival of international tourist fell by $95 \%$ in Nepal and other nations, later it was $100 \%$ after government closedown Airplanes and Airports. The sudden halt in demand has severe economic social consequences within and beyond tourism sector.

The Himalayan Times mentions, those involved in the tourism business have also been requesting the government to bring out new plans and policies to promote domestic tourism for the survival of the industry. The government of Nepal has also taken initiatives to promote domestic tourism. They celebrated the $41^{\text {st }}$ World Tourism Day on Sunday Sept 2020. Tourism Minister Yogesh Bhattarai mentioned that domestic tourism is the only way out in current scenario. In recent years, Nepalese have to start developing a trend of travelling to various new domestic destinations. Trekking, hiking and short trips have now become popular in Nepal. As a result, stakeholders' perception towards domestic tourism is changing, said Achyut Guragain, president of Nepal Association of Tour and Travel Agents. "We committed a grave mistake in the past by not prioritizing domestic tourism," Guragain added that, "Earlier, we were so busy thinking about ways to earn foreign currency, and we did not bother about promoting domestic tourism. It is after the impact of COVID-19 that our eyes opened up to the potentiality of the domestic tourism."

Mr Binayak Shah, first vice-president of Hotel Association Nepal (HAN), said that domestic tourism has been steadily flourishing in the last four to five years and Nepalese have slowly developed the trend to travel within their country. There are inquiries from 
domestic tourists for tours during the festive season Most of the hoteliers along the trekking routes did not like to accommodate domestic tourists. In the Everest region, the domestic tourists, still do not get the type of services that foreigners get." The hoteliers are of the view that domestic tourists spend less money and possess less manners to stay in hotels," (Himalayan Times, Sept, 2020) This also is a great challenge in the path of recovery.

\section{What can be done to make Nepal Covid-19 free zone or how do we justify that Nepal is a safe \& secured destination?}

This is one of the greatest challenges faced by government of Nepal's Ministry of Tourism as to how to make Nepal a Covid-19 free zone? How can they justify that it is safe destination. For this health sector should be carefully looked into and through strict measures of 'social distancing' policy and other matters this can be obtained if steps are taken. The greatest dilemma lies in the uncertainty of Covid-19. This is a great challenge in the path of recovery.

\section{To develop far-sightedness regarding visiting tourists?}

Another challenge in the path of recovery is to have far-insight by governmental and Non-Governmental organizations involved in the tourism sector as to which type of tourist will visit Nepal after Covid-19 pandemic? Journalists, nomads, backpackers, flash packers, Teflon, intrepid, wanderlust, spiritual, adventurous, elites, incipient mass, elderly, drifters, medical doctors, risk-takers, risk avoiders researchers or event participants' tourists? How many will visit in one year? How long will they stay? What kind of motivation do they need? What will be their average expenditure? What kind of marketing are we doing? What will be our new brand logo to attract tourists? How can we justify that Nepal is safe destination. ( Kunwar R, Oct $9^{\text {th }} 2020$, Face book page $8.45 \mathrm{pm}$ )

\section{How can we portray our image/ impression to those going back home?}

Another big challenge is how can we portray a good image and impress the tourist who have been here once, so that they eventually come again and again. This is not an easy task. It is a challenge to be faced by the government and those involved in Tourism Sector. This concept is exactly like selling good quality stuff, so that a buyer becomes a regular client. Hence we must develop our infrastructures, make it a safe-heaven for those who come, treat them with sincerity and goodwill, provide them quality services, entice them with attractive quality local handicrafts, to see that they are happy with the services provided and to make them feel that they are " Home Away From Home".

\section{What lessons have we learnt from COVID-19 in promotion of Tourism?}

The data gathered from the respondents brought to light that the pandemic has taught all of us a lesson that the country should be self-sufficient and not rely only on remittance. The health sector should not be neglected by the government. Beside this one must be prepared to 
face disaster or pandemics of all kinds. Those involved in Travel and Tourism sector such as the guides, mountaineers and others should not fully depend upon tourism sector only, but must try to develop other alternatives as a source of income for sustainability. One should not over exploit nature, learn to live with it rather than destroy it. If not the consequences faced will be disastrous.

Beside the above views of the respondents it can be further added that Covid-19 has made us learn great lessons, we have learnt to value money, family, and give extra care to sanitations and hygiene and the health sector. It has made us adapt to the new technology and digital world of virtual reality. This pandemic has taught us that 'Darwin's theory' "The Survival of the Fittest " is very much at work even in the $21^{\text {st }}$ century..

Thus it can be said that this pandemic has taught us great lesson. "Struggle can take place at any time, any place and it can be against anything of any kind. We have to be ready to challenge it and survive'. Be prepared for any kind of disaster/ pandemics' and face it with courage to sustain and survive is the greatest lesson learnt today.

\section{Conclusion}

Thus it can be concluded that the result and discussions obtained through analysis of the collected data from the respondents fulfill the following objectives:

- What impact does COVID-19 have in the Tourism Sector of Nepal ? As it has brought it to complete halt as a result it has great impact on the National economy..

- To find out the challenges in the path of recovery? Various challenges in the path of recovery such as unemployment, lack of poor health sector, poor policies etc.

- What lessons has COVID-19 taught in promotion of Tourism? Be prepared for any kind of disaster and pandemics, learn to be self sufficient.

- To open new venue for further research. This short research has opened new venue for further researches.

Thus it can be concluded that great lessons has been learnt from this Covid-19 global pandemics. It has made us respect nature and the struggle to survive against any situation has made us stronger to sustain our selves in all situations with or without governmental help. In the context to tourism sector at the present situation; only two things can be focused on for promotion of tourism after pandemic. 1 ) Travels Bubbles must be focused on by the Governmental Tourism Ministry so that people can slowly revive. 2) Promote domestic tourism. 
There are numerous suggestions for promotions of tourism sector after pandemics such as to develop attractive packages for the tourists and the government should give extra care to the tourism sectors as well as the government must develop Nepal as a 'Safe Zone' for tourist destination. They must justify and advertise it, so that it is known globally. Nepal must immediately join 'Travel Bubbles' and set up contracts with neighbouring nations so that members can come without being quarantined and the policy of tourist being 7 days quarantined will not help at all. Such policies will bring failure to tourism sector. Thus, the government should take advantage of this Covid-19 period and develop, the infrastructure, its health system and focus on hygiene. Beside all this a well versed person in travel and tourism must be chosen to formulate new plans and policies. All stakeholders should be prepared to provide quality services including clean healthy environment and advertise tourism with focus on health \& hygiene as a given priority to promote domestic tourism and proper management must be done in the tourism sector. They must learn to live with nature as well as develop food banks and wages for the unemployed should be provided.

Thus it can be concluded that beside these there are other minor recommendations which can be fulfilled both by the community, individual as well as the government.

\section{References}

Beirman, D. (2011). Bounce back: Tourism risk, crisis and recovery management guide, Sydeny: Pacifi c Asia Travel Association (PATA).

Denzin, N. K., \& Lincoln, Y. S ( 1994 ). Handbook of qualitative research: Thousand Oaks, CA: SAGE.

Himalayan Times, Vol. XVIV No. 351, Nov $21^{\text {st }} 2020$.

Jason, Moore. ( 2019). The Capitalocene and Planetary Justice. Maize: 6, 49-54.

Kunwar, R.R. (2010). Tourists and Tourism. Science and Industry Interface. Kathmandu: Ganga Sen Kunwar.

Kunwar, R.R. (2016). Tourism crisis and disaster management. The Gaze: Journal of Tourism and Hospitality, 7(1), 1-36

Magar Alpana Ale, September 28, 2020, Himalayan Times,

Richards, G. \& Munsters, W. (eds.) (2012) Cultural Tourism Research Methods. Wallingford: $\mathrm{CAB}$ International

Tyrrell, D.A. \& Bynoe, M.L.( 1996 ). Cultivation of viruses from a high proportion of patients with colds. Lancet: $76-77$ 
Net References

ADB. (2019). Macroeconomic update Nepal. Asian Development Bank, 7(1). [Retrieved From: https://www.adb.org/sites/default/files/institutional-document/495276/nepalmacroeconomic-update-201904.pdf, Assessed on: April 1, 2020].

BBC: "Rules of Life - Meet Aubrey". Open University. 24 October 2005. Retrieved 21 December 2012

Huang, C. Wang Y Li X et al. Clinical features of patients infected with 2019 novel coronavirus in Wuhan, China. Lancet. (2020;) (published online Jan 24.) (Retrieved, http://dx.doi.org/10.1016/S0140-6736(20)30183-5 )

ILO, 2020, COVID-19 and the world of work https://academic.oup.com/jtm/article/27/6 .

Jared Alster, Skift , Don't Discount the Impact of Covid-19's Psychological Toll on Travel's Recovery, Skift:, May 22, 2020 9:00 am

Kathmandu Post. Retrieved From: https://kathmandupost.com/ national/2020/03/04/nepalieconomy-starts-to-feel-the-pinch-as-coronavirusspreads, Assessed on: April 5, 2020]

Kunwar R, Oct $9^{\text {th }} 2020$, Face book page 'news feed, $8.45 \mathrm{pm}$

Kunwar Ramesh Raj, $19^{\text {th }}$ Oct 2020, Face book newsfeed page post.

Ranjit Sah, MD, Shailendra Sigdel, MD, Akihiko Ozaki, MD, PhD, Yasuhiro Kotera, MA, Divya Bhandari, MHS, Priyanka Regmi, MBBS, Ali A Rabaan, PhD, Rachana Mehta, MSc, Mahesh Adhikari, MD, Namrata Roy, MBBS (.Issue 6, August 2020 ) Author Notes Journal of Travel Medicine, Volume 27, , taaa105, https://doi. org/10.1093/jtm/taaa105,Published:07 July 2020 assessed/ Nov 2, 2020.

Shrestha R, Shrestha S, Khanal P, Bhuvan KC. ( 2020 ), Nepal's first case of COVID-19 and public health response .JTravelMed 2020. doi:10.1093/jtm/taaa024.2

Subba, S. (2020). Nepal's economy, already weak, takes direct hit. Nepali Times. [Retrieved From(https://www.nepalitimes.com/here-now/nepals-economyalready-weak-takesdirect-hit/, Assessed on: April 2, 2020)

The world Bank In Nepal (2020) https://www.worldbank.org/en/country/nepal/overview(1 June 2020, date last accessed)

WHO Report ( 2020 ) Novel coronavirus (2019-nCoV)—Situation report-10-30 January. https://www.who.int/docs/default-source/coronaviruse/situation-reports/20200130sitrep-10-ncov.pdf?sfvrsn=d0b2e480_2, Date accessed: Oct 7, 2020) 